Original Research Paper

\title{
Kajian Morfologi dan Mikromorfologi (Sisik serta Trikoma) 4 Jenis Pyrrosia Mirb. (Polypodiaceae) Di Provinsi Riau
}

\author{
Nery Sofiyanti ${ }^{1 *}$, Mayta Novaliza Isda ${ }^{1}$ \\ ${ }^{1}$ Jurusan Biologi Fakultas Matematika dan Ilmu Pengetahuan Alam Universitas Riau
}

Article history

Received: 20 September 2018

Revised: 18 Oktober 2018

Accepted: 04 November 2018

Published: 21 November 2018

*Corresponding Author:

Nery Sofiyanti,

Jurusan Biologi Fakultas

Matematika dan Ilmu

Pengetahuan Alam Universitas

Riau

Kampus Bina Widya Jl.

Pekanbaru Bangkinang KM 12.5,

Panam, Pekanbaru, Riau

Indonesia

Email:

nery.sofiyanti@lecturer.unri.ac.id

\begin{abstract}
Abstrak : Pyrrosiamerupakan golongantumbuhan paku epifit dari famili Polypodiaceae. Penelitian ini bertujuan untuk mengkarakterisasi morfologi (rhizoma, ptiolus dan lamina) dan mikromorfologi (sisik dan trikoma) dari 4 jenis Pyrrosia yang umum dijumpai di Provinsi Riau, yaitu Pyrrosia heterophylla, Pyrrosia lanceolata, Pyrrosia longifolia dan Pyrrosia piloseilloides.Pengambilan sampel dilakukan dengan metode eksplorasi, sampel yang dikoleksi dikarakterisasi, dibuat herbarium, dan diidentifikasi. Karakter mikromorfologi diamati dan didokumentasikan menggunakan Mickroskop LCD (Celeron). Hasil pengamatan ditabulasikan, disajikan dalam bentuk gambardan dianalisis secara deskriptif. Hasil karakterisasi morfologi menunjukan variasi pada organ yang diamati, terutama pada ukuran ptetiolus, bentuk dan ukuran lamina. Hasil pengamatan pada sisik menujukan variasi pada warna sisik, jumlah rambut pada sisik dan posisinya. Sedangkan trikoma pada ptiolus dan lamina menunjukan persamaan bentuk yaitu stelata. Karakter morfologi dan mikromorfologi yang diamati pada penelitian ini sangat mendukung status taksonomi setiap jenisPyrrosia.
\end{abstract}

Kata kunci : Paku, rhizom, lamina, ptiolus, sisik, trikoma

Abstract : Pyrrosia is epiphytic fern belongs to Family Polipodiaceae. This research aimed to characterized the morphology (rhizome, ptiole, laminae) and micromorphology (scale and trichome) of 4 Pyrrosia species from Riau Province, i.e. Pyrrosia heterophylla, Pyrrosia lanceolata, Pyrrosia longifolia dan Pyrrosia piloselloides. Samples were collected using exploration method, samples were then documented, characterized, prepared for herbarium and identified. The micromorphological characters were observed and documented using LCD Microscope (Celeron). The observation results were tabulated, presented in figures and descriptively analyzed. The morphological characterization showed variation of observed plant parts, especially on ptiole size, shape and size of lamina. The scale observation showed that scale color, as well as number and position of hair on scale varied within the species observed. While trichome of petiole and laminae showed similar form, stellate trichome. Morphological and micromorphological characters observed in this study supports the taxonomical status of each Pyrrosia species.

Key words: fern, rhizome, laminae, ptiole,scale, trichome

\section{Pendahuluan}

PyrrosiaMirb. merupakan golongan paku epifit dari Famili Polypodiaceae (Sundue \& Kessler 2008; Zhanget al. 2013). Pada umumnya jenis-jenis Pyrrosia mempunyai daun tunggal (Vascues et al. 2017), tebal, berdaging dan kaku (Sofiyanti et al.
2015). Berdasarkan hasil inventarisasi yang telah dilakukan di Provinsi Riau, telah dilaporkan sebanyak 6 jenis Pyrrosia, namun hanya 4 jenis yang banyak dijumpai dibanyak daerah diprovinsi ini, yaitu Pyrrosia heterophylla, Pyrrosia lanceolata, Pyrrosia longifolia dan Pyrrosia 
piloselloides (Yusna et al. 2016; Wulandari et al. 2016; Marpaung et al. 2016, Sofiyanti et al. 2015a, 2017abc). Sedangkan 2 jenis Pyrrosia lainnya yaitu Pyrrosia angustatadan Pyrrosia rasamalae, jarang dijumpai di Provinsi Riau (Sofiyanti et al. 2015a; Sofiyanti et al. 2017cd tidak dipublikasikan).

Penggunaan karakter morfologi dalam kajian taksonomi tumbuhan paku telah banyak dilaporkan karena karakter ini merupakan karakter yang paling mudah diamati dan dapat dijadikan dasar identifikasi suatu taksa (Sofiyanti et al. 2015b; 2016) serta menunjang klasifikasinya (Kluge \& Kesler 2007; Oloyede 2012; Vasco et al. 2013). Sedangkan karakter mikromorfologi termasuk sisik dan trikom juga sangat mendukung identifikasi dan pembedaaan suatu jenis paku karena karakter ini menunjukan ciri khas suatu jenis (Wagner et al. 1991, 2004). Oleh karena itu, kajian karkter morfologi dan mikromorfologi tumbuhan, termasuk tumbuhan paku diperlukan dalam mendukung status taksonominya. Kajian morfologi tumbuhan paku di Provinsi Riau telah dilaporkan oleh Sofiyanti 2013, Sofiyanti et al. 2015 dan 2016, namun kajian mikromorfologi yang meliputi sisik dan trikoma belum pernah dilaporkan. Sehingga data yang disajikan pada kajian ini merupakan data baru bagi jenis-jenis Pyrrosia di Riau, sehingga dapat dijadikan karakteristik dalam penentuan jenis. Oleh karena itu, kajian ini bertujuan untuk untuk mengkarakterisasi morfologi (rhizoma, ptiolus dan lamina) dan mikromorfologi (sisik dan trikoma) dari 4 jenis Pyrrosia yang umum dijumpai di Provinsi Riau

\section{Bahan dan Metode}

Table 1. Spesimen yang diteliti

\section{Waktu dan tempat}

Penelitian ini telah dilakukan dari bulan Juni - September 2018. Pengambilan sampel dilakukan dengan metode Namau (1992), Ekplorasi dilakukan di Pekanbaru, Siak, Kampar, Rokan Hilir dan Rokan Hulu. Khusus pengambilan sampel untuk pengamatan mikromorfologi berdasarkan dan dilakukan di Pekanbaru untuk mendapatkan sampel yang segar.

\section{Karakterisasi morfologi, pembuatan herbarium dan identifikasi}

Pembuatan karakterisasi morfologi dan herbariummengacu pada Seshagirirao (et al.2016) sedangkan identifikasi berdasarkan Piggott (1998) Sofiyanti et al.(2015a). Bagian yang dikarakterisasi adalah akar, rhizome, daun dan sorus.

\section{Pengamatan Mikromorfologi}

Organ yang diamati adalah sisik pada rhizome, trimoma pada ptiolus dan lamina. Pengamatan mikromorfologi mengacu pada Murtaza (2008) dan dilakukan di Laboratorium Botani, Jurusan biologi FMIPA Universitas Riau. Sisik dan trikoma diambil menggunakan jarum preparat. Trikoma diletakan pada gelas benda dan ditetesi dengan larutan gliserin sebelum ditutup menggunakan gelas penutup Preparat diamati dan didokumentasikan menggunakan Microskop LCD (Celeron). Tabel 1 menyajikan spesimen untuk pengamatan morfologi dan mikromorfologi.

\begin{tabular}{|c|c|c|c|c|}
\hline NO. & Nama jenis & Kode Spesimen & MO & MI \\
\hline 1. & Pyrrosia heterophylla(L.)M.G. Price & $\begin{array}{l}\text { PHS, Siak; } \\
\text { PH1, PH2, Simpang Tiga; PH3* } \\
\text { Pekanbaru, Riau. Nery Sofiyanti } 2018\end{array}$ & $\mathrm{R}, \mathrm{P}, \mathrm{L}$ & SR, TP, TL \\
\hline 2. & Pyrrosia lanceolata(L.) Farwell. & $\begin{array}{l}\text { PLARH, Rokan Hilir; PLA1*, Pekanbaru, } \\
\text { Riau. Nery Sofiyanti } 2018\end{array}$ & $\mathrm{R}, \mathrm{P}, \mathrm{L}$ & SR, TP, TL \\
\hline 3 & Pyrrosia longifolia(Burm. f.) Morton & $\begin{array}{l}\text { PLORH, R0kan Hulu; PLO1, PLO2*, } \\
\text { Pekanbaru, Riau. Nery Sofiyanti } 2018\end{array}$ & $\mathrm{R}, \mathrm{P}, \mathrm{L}$ & SR, TP, TL \\
\hline 4. & Pyrrosia piloselloides(L.)M.G. Price & $\begin{array}{l}\text { PPKA Kampar; PPSI Siak, Pekanbaru } \\
\text { Riau. Nery Sofiyanti } 2018\end{array}$ & $\mathrm{R}, \mathrm{P}, \mathrm{L}$ & SR, TP, TL \\
\hline
\end{tabular}

Keterangan : untuk penyebutan nama jenis selanjutnya, genus akan disingkat menjadi $\mathrm{P} ; \mathrm{MO}=$ morfologi, $\mathrm{MI}=$ Mikromorfologi, $\mathrm{R}=$ Rhizom, $\mathrm{P}=$ ptiolus, $\mathrm{L}=$ Lamina, $\mathrm{SR}=$ sisik pada rhizome, $\mathrm{TP}=$ trikom pada ptiolus, $\mathrm{TL}=$ trikom pada laminae steril. * specimen yang digunakan untuk pengamatan mikromorfologi.

Analisis data 
Hasil karakterisai morfologi dan mikromorfologi dokumentasikan dan disajikan dalam bentuk tabel dan gambar kemudian dianalisis secara deskriptif mengikuti Haou et al. (2011).

\section{Hasil dan Pembahasan}

Pyrrosia merupakan anggota famili Polypodiaceae yang pada umumnya merupakan paku epifit. Batang Pyrrosia berupa rhizom yang menjalar
(Piggot 1998). Pyrossia dapat dibedakan dari genus lain pada famili. Polypodiaceae dengan adanya rhizoma panjang dan menjalar, serta daun tunggal yang pada umumnya tebal dan berdaging. Sebanyak 4 jenis Pyrrosia diamati pada kajian ini. Pengamatan morfologi dari rhizom, tangkai daun dan daun 4 jenis Pyrrosia dariProvinsi Riaumenunjukan variasi karakter. Tabel 2 menunjukan perbandingan karakter morfologi pada jenis Pyrrosia yang diteliti.

Tabel 2. Perbandingan karakter morfologi 4 jenisPyrrosia di Provinsi Riau.

\begin{tabular}{|c|c|c|c|c|c|}
\hline NO. & KARAKTER & PHE & PLA & PLO & PPI \\
\hline & Rhizoma & & & & \\
\hline 1. & Pertumbuhan & Menjalar & Menjalar & Menjalar & Menjalar \\
\hline 2. & Warna & Coklat tua & Coklat tua & Coklat tua & Coklat \\
\hline 3. & Diameter $(\mathrm{mm})$ & \pm 2.5 & \pm 2.5 & \pm 3.0 & $\pm 1.5-2.0$ \\
\hline \multirow[t]{2}{*}{4.} & Sisik & Ada & Ada & Ada & Ada \\
\hline & Ptiolus & & & & \\
\hline 1. & Warna & Coklat tua & Hijau & Coklat kehitaman & coklat \\
\hline 2. & Panjang $(\mathrm{cm})$ & \pm 0.2 & \pm 4 & \pm 10 & \pm 0.15 \\
\hline 3. & Diameter (mm) & \pm 3 & \pm 3 & \pm 4 & \pm 1.5 \\
\hline \multirow[t]{2}{*}{4.} & Trikoma & Ada & Ada & Ada & Ada \\
\hline & Ptiolus & & & & \\
\hline 1. & Warna & Coklat tua & Hijau & Coklat kehitaman & coklat \\
\hline 2. & Panjang $(\mathrm{cm})$ & \pm 0.2 & \pm 0.4 & \pm 15 & \pm 0.5 \\
\hline 3, & Diameter $(\mathrm{mm})$ & \pm 3 & \pm 3 & \pm 4 & \pm 1.5 \\
\hline \multirow[t]{2}{*}{4.} & Trikoma & Ada & Ada & Ada & Ada \\
\hline & Lamina steril & & & & \\
\hline 1. & Bentuk & Oblong & Lanset & Linear & Membulat \\
\hline 2. & Ukuran $(\mathrm{cm})$ & $\pm 2.5 \times 0.8$ & $\pm 10 \times 1.8$ & $\pm 20 \times 2.5$ & $\pm 2.0 \times 1.5$ \\
\hline \multirow[t]{2}{*}{3.} & Trikoma & Ada & Ada & Ada & Ada \\
\hline & Lamina fertil & & & & \\
\hline \multirow[t]{2}{*}{1.} & Bentuk & Linear & Oblong & Linear & Linear \\
\hline & & Ujung menyempit & Ujung menyempit & Ujung membulat & Ujung membulat \\
\hline 2. & Ukuran $(\mathrm{cm})$ & $\pm 5 \times 5$ & $\pm 15 \times 1.5$ & $\pm 35 \times 3$ & $\pm 10 \times 0.7$ \\
\hline 3. & Sori & Garis & Oval - membulat & Oval - membulat & Garis \\
\hline
\end{tabular}

Keterangan $:$ PHE $=P$. heterophylla, $\mathrm{PLA}=P$. lanceolata, $\mathrm{PLO}=P$. longifolia, $\mathrm{PPI}=P$. piloselloides, $\mathrm{TA}=$ Tidak ada

Karakter rhizom pada tumbuhan paku merupakan salah satu karakter penting dalam kajian taksonomi (Ning et al. 2014). Pola pertumbuhan rhizoma paku yang pernah dilaporkan sebelumnya adalah tegak, agak menjalar (Sofiyanti et al 2015ab), menjalar dan tumbuh pendek menyerupai batang sejati (Piggot 1998; Kluge \& Kessler 2007). Sedangkan rhizoma pada semua jenis Pyrrosia menunjukan persamaan pola pertumbuhan yaitu menjalar (Jhons 1996; Piggot 2018). Karakter rhizome pada Famili Polypodiaceae telah dilaporkan oleh Gay (2018) pada genus Lecanopteris Reinw. Warna rhizoma yang dijumpai pada kajian ini adalah coklat tua, kecuali pada $P$. piloselloides berwarna coklat. Diameter rhizome terbesar dijumpai pada $P$. longifolia (sekitar $4 \mathrm{~mm}$ ) dan terkecil pada $P$. piloselloides (sekitar 2mm). Rhizoma diselubung oleh sisik yang tersusun rapat. Adanya sisk pada rhizome juga merupakan karakteristik genus Pyrrosia. Variasi bentuk sisik rhizoma pada paku yang pernah dilaporkan sebelumnya antara lain 
bentuk bulat, peltata tidak beraturan, lanset, linier, dan stelata (Jhon 1996).

Ptiolus (tangkai daun) merupakan bagian yang mendukung helai daun dan melekat pada rhizom. Karakter ptiolus juga merupakan karakter yang bernilai taksonomi baik pada tumbuhan tingkat tinggi maupun tinggat rendah (Kocsis \& Borhidi 2003; Taiwo \& Akinwuni 2015). Pada kajian ini, variasi ptiolus dijumpai pada warna dan panjangnya. Warna petiole yang dijumpai adalah coklat tua $(P$. heterophylla), coklat kehitaman ( $P$. longifolia,) dan coklat ( $P$. piloselloides). Sedangkan $P$. Lanceolatamempunyai warna ptiolus yang berbeda dengan ketiga jesis lainnya yaitu hijau. Untuk panjang ptiolus, jenis yang mempunyai ukuran terpanjang adalah $P$. longifolia (sekitar 15 cmatau lebih) dan paling pendek adalah $P$. piloselloides (sekitar $2 \mathrm{~mm}$ ). Pada penelitian ini dapat diketahui bahwa warna dan panjang ptiolus merupakan karakter yang dapat digunakan sebagai pembeda setiap jenis.

Berdasarkan tipe daunnya semua jenis paku Pyrrosia yang dikaji mempunyai tipe daun tunggal, karena setiap tangkai daun hanya mendukung 1 helai daun (lamina) saja. Pada paku dimorfik, lamina terbagi menjadi 2 macam yaitu lamina steril dan lamina fertil dan masing masing lamina berada pada tangkai daun yang berbeda (Piggott 1998). Menurut Hovenkamp (1986), jenis jenis Pyrrosia tergolong dalam 10 kelompok berdasarkan karakter sori pada daun fertil. Pada penelitian ini hanya dijumpai 2 kelompok yaitu kelompok $P$. lanceolatadan kelompok $P$. piloselloides. Jenis-jenis yang tergolong pada kelompok $P$. lanceolata adalah jenis yang mempunyai sori oval atau membulat, yang meliputi $P$. lanceolata dan $P$. longifolia. Sedangkan jenisjenis yang tergolong $P$. piloselloides mempunyai sori memanjang seperti dijumpai pada $P$. piloselloides.

\section{Deskripsi morfologi}

Pyrrosia heterophylla (L.) M.G. Price. (Gambar 13)

Rhizom panjang menjalar, coklat tua, diameter sekitar $1.5 \mathrm{~mm}$, berisik rapat. Ental steril : ptiolus coklat tua, panjang sekitar $2 \mathrm{~mm}$, diameter 3 $\mathrm{mm}$, bertrikoma; lamina tungal, oblong, ukuran \pm 2.5x0.8. Ental fertil : linear, ujung menyempit, bentuk garis, ukuran $\pm 5 \times 5$. Sori berbentuk garis.

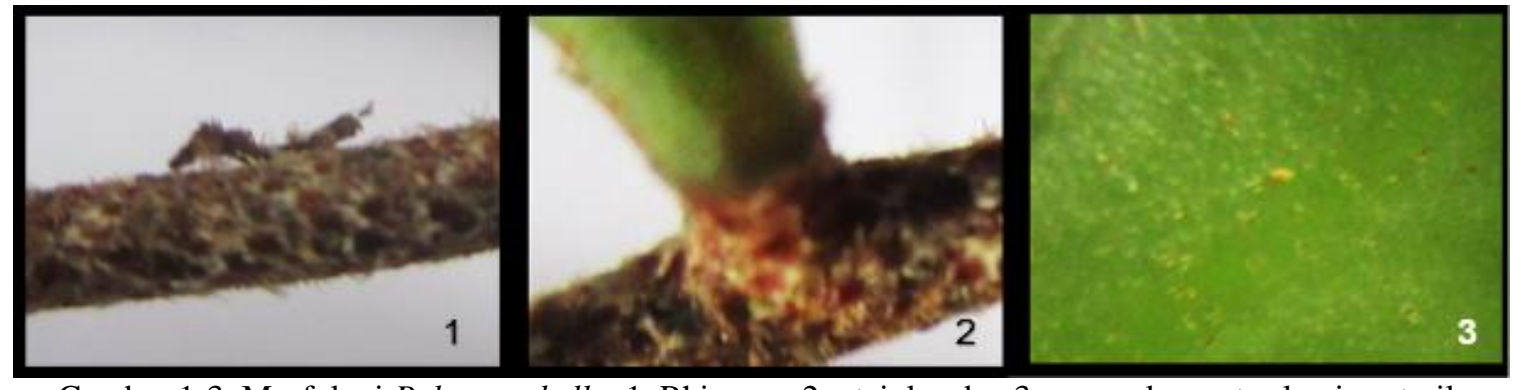

Gambar 1-3. Morfologi P. heterophylla. 1. Rhizome, 2. pteiolus dan 3. permukaan atas lamina steril.

Pyrrosia lanceolata (Linnaeus) Farwell, Amer.

Midl. Naturalist. 12: 245. 1930. (Gambar 4-6).

Rhizom panjang menjalar, coklat tua, diameter sekitar $\pm 2.5 \mathrm{~mm}$, berisik rapat. Ental steril : ptiolus hijau, panjang sekitra $4 \mathrm{~mm}$, diameter $3 \mathrm{~mm}$, bertrikoma; lamina tungal, lanset, ukuran \pm 10x1.8 $\mathrm{cm}$. Ental fertil : pteiolus coklat kehitaman, laminaOblong, Ujung menyempit, ujung menyempit, bentuk garis, ukuran $\pm 15 \times 1.5 \mathrm{~cm}$. Sori bulat.
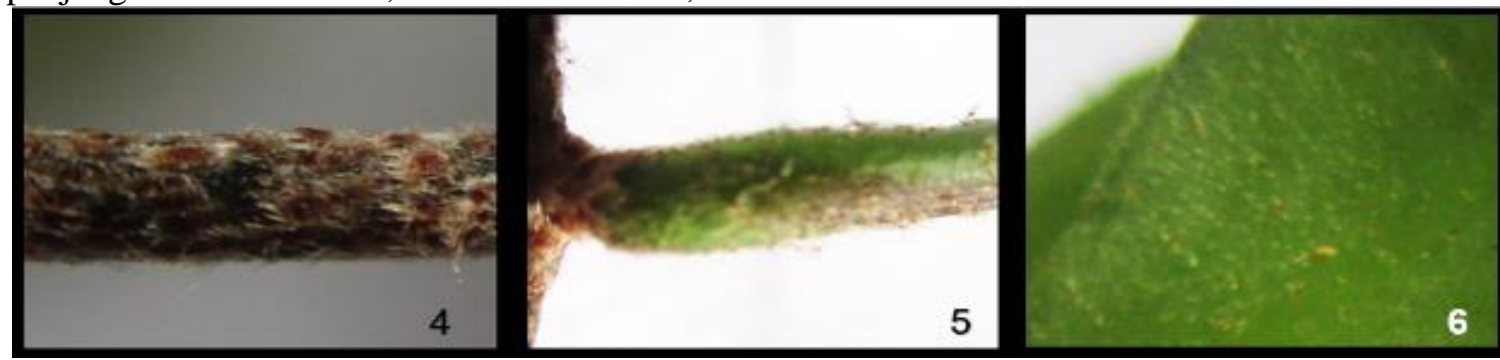

Gambar 4-6. Morfologi P. lanceolata. 4. Rhizome, 5. ptiolus dan 6. permukaan atas lamina steril. 
Pyrrosia longifolia (Burm. f.) Morton, J. Wash. Acad. Sci. 36: 168. 1946. (Gambar 7 -9).

Rhizom panjang menjalar, coklat tua, diameter sekitar $\pm 3 \mathrm{~mm}$, berisik rapat. Ental steril : ptiolus Coklat kehitaman, panjang sekitar $10 \mathrm{~mm}$, diameter
$4 \mathrm{~mm}$, bertrikoma; lamina tungal, lanset, ukuran \pm 10x1.8 cm. Ental fertil : Oblong, ujung menyempit, ujung menyempit, bentuk linear, ukuran $\pm 15 \times 1.5$ $\mathrm{cm}$. Sori berbentuk bulat.

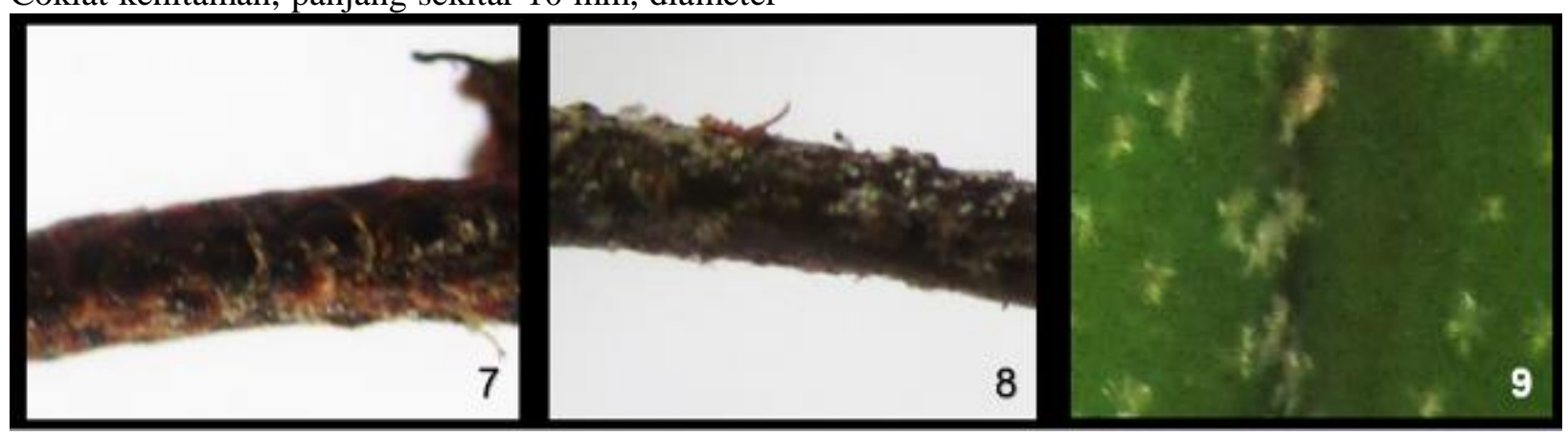

Gambar 7-9. Morfologi P. longifolia. 7. Rhizom, 8. pteiolus dan 9. permukaan atas lamina steril.

Pyrrosia piloselloides (L.) M.G. Price. Kalikasan 3: 176. 197 (Gambar 10 - 12).

Rhizom panjang menjalar, coklat tua, diameter sekitar $\pm 3 \mathrm{~mm}$, berisik rapat. Ental steril : ptiolus coklat, panjang sekitar $10 \mathrm{~mm}$, diameter $\pm 0.5 \mathrm{~mm}$, bertrikoma; lamina tungal, membulat - oval, ukuran $\pm 2.0 \times 1.5 \mathrm{~cm}$. Ental fertil : ptiolus coklat, panjang sekitar $10 \mathrm{~mm}$, diameter $\pm 0.5 \mathrm{~mm}$, bertrikoma; lamina tungal, linear, ukuran $\pm 10 \mathrm{x} 0.7 \mathrm{~cm}$. Sori berbentuk garis.

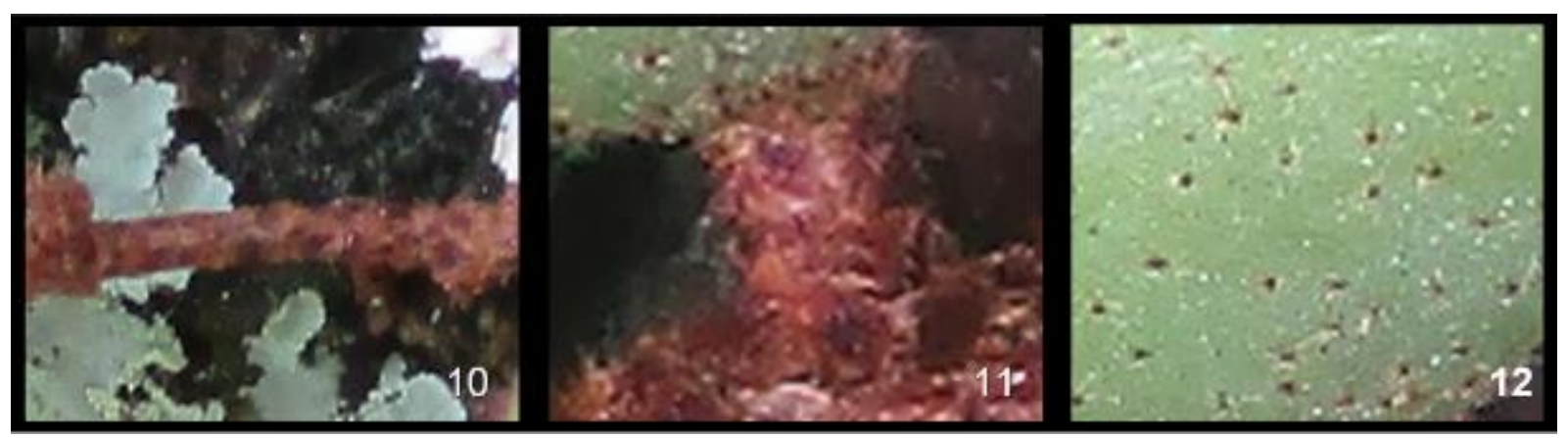

Gambar 10-12. Morfologi P. heterophylla. 10. Rhizom, 11. pteiolus dan 12. permukaan atas lamina steril.

\section{Kunci identifikasi 4 jenis Pyrrosia di Provinsi} Riau

1. a. Panjang ptiolus sekitar $1.5-2.0 \mathrm{~mm}$, sori garis 2

b. Panjang ptiolus $4-10 \mathrm{~mm}$ atau lebih, sori oval-membulat 3

2. a. Daun steril membulat atau oval, ukuran skitar 2 x.1.5 cm; daun fertil ujung membulat ............... P. piloselloides

b. Daun steril oblong, tengah melebar, ukuran $2.5 \times 0.8 \mathrm{~cm}$; daun fertile ujung menyempit .....P. heterophylla

3. a. Daun steril lanset, ukuran skitar $10 \times 1.8$ $\mathrm{cm}$; daun fertil oblong .P. lanceolata b. Daun steril oblong, tengah melebar, ukuran $20 \times 2.5 \mathrm{~cm}$; daun fertile linear ......................... longifolia

\section{Mikromorfologi sisik dan trikoma}

Pada kajian mikromorfologi, bagian yang diamati adalah sisik pada rhizome serta trikoma pada ptiolus dan lamina. Bentuk sisik yang dijumpai pada penelitian ini adalah sirkular dengan tepi menyerupai rambut serta oblong - ovatus dengan pangkal membulat dan lebih lebar. Bentuk sisik sirkular dijumpai pada 3 jenis Pyrrosia yaitu $P$. heterophylla, $P$. lanceolata dan $P$. piloselloides, sedangkan pada $P$. longifolia mempunyai bentuk 
sisik oblong - ovatus dengan bagian pangkal yang melebar. Perbedaan lain yang dijumpai pada sisik adalah karakter tepi sisik.P. longifolia mempunyai tepi sisik cenderung rata, sedangkan ketiga jenis lainnya tepi sisik menyerupai rambut dengan ujung berlepasan. Pada pengamatan panjang sisik ditemukan perbedaaan tiap jenis, yaitu $\pm 0.6 \mathrm{~mm} P$. heterophylla dan terpanjang (sekitar $2 \mathrm{~mm}$ ) pada $P$. longifolia. Karakteristik sisik pada tumbuhan paku menjadi salah satu karakter yang mendukung kajian taksonominya, karena setip jenis menunjukan karakter berbeda (Jhon 1996). Gambar 2 menunjukan morfologi sisik dan trikoma yang diamati. Sedangkan tabel 3 menyajikan karakterisasi mikromorfologinya.
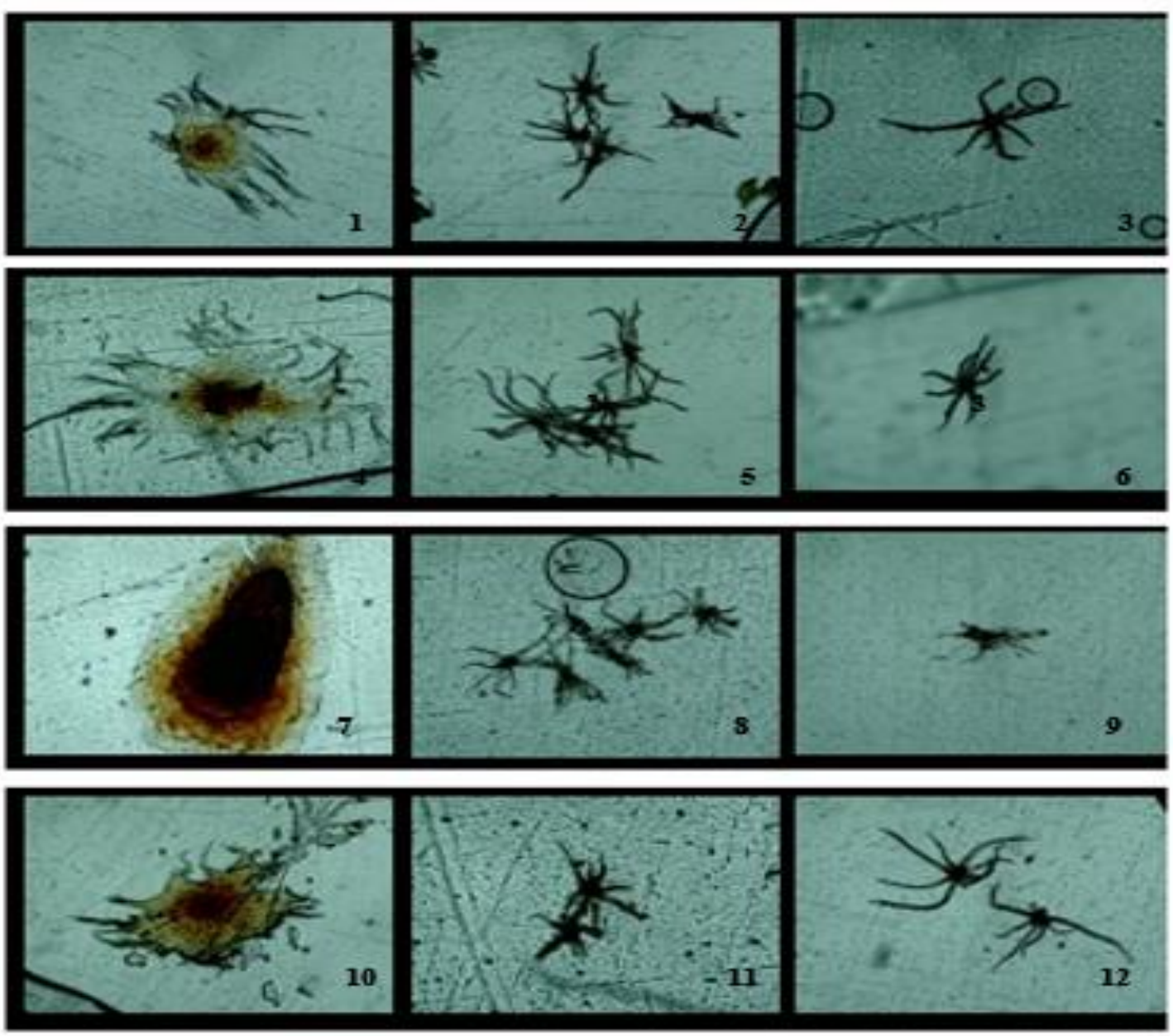

Gambar 1. Mikromorfologi sisik pada rhizoma (kiri), trikoma pada ptiolus (tengah) dan lamina steril (kanan). 1-3. $P$. heterophylla, 4-6. P. lanceolata, 7-9. P. longifolia, 10-12. P. piloselloides.

Tabel 3. Perbandingan karakter mikromorphologi Pyrrosia di Provinsi Riau.

\begin{tabular}{llllll}
\hline NO. & KARAKTER & PHE & PLA & PLO & PPI \\
\hline Sisik pada rhizoma & & & & \\
\hline 1. & Bentuk & Sirkular & Sirkular & Oblong - ovate. & Sirkular \\
\hline 2. & Panjang sisik $(\mathrm{mm})$ & \pm 0.6 & \pm 2.0 & $\pm 2.0-3.0$ & \pm 1.0 \\
\hline 3. & Warna tengah sisik & Coklat muda & Coklat & Coklat tua & Coklat \\
\hline 4. & Tepi sisik & Menyerupai rambut & $\begin{array}{l}\text { Menyerupai } \\
\text { rambut }\end{array}$ & Rata & $\begin{array}{l}\text { Menyerupai } \\
\text { rambut }\end{array}$ \\
\hline 5. & Warna tepi sisik & Putih & Puth & $\begin{array}{l}\text { Putih } \\
\text { kekuningan }\end{array}$ & Coklat muda \\
\hline 6. & Jumlah rambut & \pm 20 & \pm 35 & $>100$ & \pm 40 \\
\hline
\end{tabular}




\begin{tabular}{|c|c|c|c|c|c|}
\hline NO. & KARAKTER & PHE & PLA & PLO & PPI \\
\hline \multicolumn{6}{|c|}{ Trikoma pada ptiolus } \\
\hline 1. & Warna & Coklat & $\begin{array}{l}\text { Putih } \\
\text { kecoklatan }\end{array}$ & Putih & Coklat tua \\
\hline 2. & Bentuk & Stelata & Stelata & Stelata & Stelata \\
\hline 3. & Jumlah lengan & $8-9$ & $8-9$ & $8-9$ & $8-9$ \\
\hline \multicolumn{6}{|c|}{ Trikoma pada lamina steril } \\
\hline 1. & Warna & Putih & Putih & Putih & $\begin{array}{l}\text { Putih } \\
\text { kehitaman }\end{array}$ \\
\hline 2. & Bentuk & Stelata & Stelata & Stelata & Stelata \\
\hline 3. & Jumlah lengan & $8-9$ & $8-9$ & $8-9$ & $8-9$ \\
\hline
\end{tabular}

Trikom (jamak trikoma) merupakan struktur seperti rambut yang dijumpai pada berbagai organ tumbuhan seperti batang, ptiolus, lamina daun maupun organ reproduktif. Trikoma menjadi karakter yang dapat digunakan dalam kajian taksonomi tumbuhan paku (Roux et al. 1992). Pada penelitian ini bentuk trikoma yang dijumpai pada ptiolus dan lamina semua jenis Pyrrosia mempunyai kesamaan bentuk yaitu bentuk bintang atau stelata. Trikoma bentuk bintang memang merupakan karakteristik jenis-jenis Pyrrosia (Zhang et al. 2013). jumlah lengan trikoma dari semua jenis menujukan persamaa ( $8-9$ lengan), baik pada ptiolus maupun lamina. Trikoma berbentuk garis juga ditemukan pada beberapa jenis paku seperti Pteris vittata (Wenzue et al. 2005) dan anggota Pteridaceae (Imeida et al. 2017).

\section{Kesimpulan}

Kajian morfologi 4 jenis Pyrrosia pada penelitian ini memberikan karakteristik yang berbeda pada setiap jenisnya, terutama pada ukuran rhizome, ukuran dan bentuk lamina steril dan fertil serta bentuk sorus. Untuk karakter mikromorfologi, karekter pada sisik lebih banyak menunjukan variasi antar jenis dibandingkan karakter trikoma, sehingga sisik pada rhizome Pyrrosia dapat dijadikan pembeda antar jenisnya. Semua jenis Pyrrosia yang diamati mempunyai bentuk trikoma yang sama yaitu berbentuk bintang (stelata), karakter ini dapat dijadikan pendukung status taksonomi pada tingkat genus.

\section{Ucapan terima kasih}

Penelitian ini didanai melalui hibah Penelitian Berbasis Kompetensi (HIKOM) DRPM Kemenristek Dikti 2018.

\section{Daftar Pustaka}

Gay, H. 2008. Rhizome structure and evolution in the ant-associated epiphytic fern Lecanopteris Reinw. (Polypodiaceae). Botanical Journal of the Linnean Society 113(2): 135160, https://doi.org/10.1111/j.10958339.1993.tb00335.x

Haou, S. de Bélair, G. \&Viane, RLL.2011. Inventory of the ferns (filicopsida) of Numidia's (NorthEastern Algeria) .International Journal of Biodiversity and Conservation 3(6): 206-223, June 2011

Imeida, T., \& Salino, A., Dubuisson, J.\& Hennequin, S. 2017. Adetogramma (Polypodiaceae), a new monotypic fern genus segregated from Polypodium. PhytoKeys. $78 . \quad 109-131$. 10.3897/phytokeys.78.12189.

Johns, R.J., 1996. An Introduction to the Ferns and Ferns Allies' Kew personal communication.http://www.svenlandrein.co $\mathrm{m} /$ systematiccoursepages/ferns.html.

Kluge, J. \& Kessler, M. 2007. Morphological Characteristics Of Fern Assemblages Along An Elevational Gradient: Patterns And Causes Ecotropica 13: 27-43.

Kocsis, M. \&Borhidi, AL. 2013. Petiole anatomy of some Rubiaceae genera. Acta Botanica Hungarica 45: 345-353. 
Marpaung AA, Sofiyanti N, Iriani D, Fitmawati. 2016. Morfologi spora paku Pteridaceae di Hutan PT. CPI Rumbai Riau. Jurnal Riau Biologia 1(2): 148-154.

Murtaza, G., S. Majid, R. Asghar, Z.H. Malik. 2008. Morphopalynological and anatomical studies on fan fern Schizaea dichotoma (L.) Smith from Neelum Valley, Azad Kashmir. Pakistan Journal of Botany 40(1) : 59-63. https://www.pakbs.org/pjbot/.

Namau HN. 1992. Germplasm Exploration and Collection. Dinteria 23: 50-54.

Ning, T., YongDong, W. Wu, Z.\& ZiKun, J. 2014. A new structurally preserved fern rhizome of Osmundaceae (Filicales) Ashicaulis wangii sp. nov. from the Jurassic of western Liaoning and its significances for palaeobiogeography and evolution. Science China Earth Science 57(4):671-681. DOI: 10.1007/s11430-013-4767-2\}

Oloyede, F. 2012. Survey Of Ornamental Ferns, Their Morphology And Uses For Environmental Protection, Improvement And Management. Ife Journal Of Science 14(2): $245-252$.

Piggott, A.G. 1998. Fern of Malaysia in Color. Tropical Press Sdn.Bhd.,Malaysia.

Roux, J.P., van der Walt, J.J.A. and van der Merwe, A.B.. 1992. Systematic studies in the genus Mohria (Pteridophyta: Anemiaceae) I. Comparative morphology and anatomy of the rhizome and frond. S.AfrJ.Bot., 58(2): $83-8983$.

Seshagirirao, K., Hari, K., Kusuma, V., Badithi, N., Kizukala, J.\& Basimalla, KR.,Rutuparna, J. \& Dhokne, KB. 2016. Preparation Of Herbarium Specimen For Plant Identification And Voucher Number. Roxburghia. 6. 111-119.

Sofiyanti N, D. Iriani, A.A. Roza. 2015a. Morfologi tumbuhan Paku di Taman Hutan Raya
Sultan Syarif Hasyim, Riau. Unri Press, Pekanbaru.

Sofiyanti N, Iriani D, Fitmawati, Roza AA. 2015b. Stenochlaena riauensis (Blechnaceae), A new fern species from Riau, Indonesia. Bangladesh Journal of Plant Taxonomy 22(2): 137-14. DOI http://dx.doi.org/10.3329/bjpt.v22i2.26075.

Sofiyanti N, Iriani D, Fitmawati, and Marpaung, A.A. 2017a. A Note on the Fern (Pteridophyte) Diversity from Riau.Applied Science and Technology 1(1):478 - 481.

Sofiyanti N, Iriani D, Fitmawati, Marpaung AA. 2017b. Karakteritik dan Metode Pembuatan Preparat Spora Pteridoflora. UNRI Press, Pekanbaru.

Sofiyanti N, Iriani D, Fitmawati, 2017c. Analisis Potensi Tumbuhan Paku di daerah gambut di Riau sebagai agen terapeutik. Laporan PTUPT (tidak dipublikasikan).

Sofiyanti N, MN Isda., 2017d. Pengembangan metode SEM dan Analisis DNA tumbuhan paku di Riau dan Kepulauan Riau. Laporan PBK (tidak dipublikasikan).

Sundue, M. \&Kessler, M. 2008. New species and new records of the fern genus Terpsichore (Polypodiopsida:

Polypodiaceae) from Bolivia. Organisms Diversity \& Evolution 8(2): 163.e1163.e10. https://doi.org/10.1016/j.ode.2007.06.003.

Taiwo, A. \& Akinwumi, A. 2015. Petiole Anatomy of the Genus Basella in South Western Nigeria. Journal of Plant Sciences 10: 3541.

Vasco, A., Moran, R.C., \&Ambrose, B.A. 2013. The evolution, morphology, and development of fern leaves. Frontier in plant science 4(345): 1 - 16.doi: 10.3389/fpls.2013.00345.

Vasques, D.T., Ebihara, A. \& Ito, M. 2017. The felt Fern Genus Pyrrosia Mirbel (Polypodiaceae) : a new subgeneric 
classification with moleculer phylogenetic analysis based on three plastid markers. Acta Phytotax. Geobot 68(2): 65 - 68.

Wagner, G. J., Wang, E., Shepherd, R. W. et al., New approaches for studying and exploiting an old protuberance, the plant trichome, Annals of Botany, 2004, 93: 311.

Wenxue, L. Tongbin, C., Yang, C. \&Mei, L. 2005. Role of trichome of Pteris vittata $\mathrm{L}$. in arsenic hyperaccumulation Science in China Ser. C Life Sciences 2005 Vol.48 No.2 148-154.

Wulandari D, Sofiyanti N, \&Fitmawati. 2016. Keanekaragaman Jenis Polypodiaceae Di Hutan PT. CPI Rumbai Provinsi Riau
Berdasarkan Karakter Morfologi. Jurnal Riau Biologia 1(2): 135-139.

Yusna M, Sofiyanti, N. \&Fitmawati. 2016. keanekaragaman pteridaceae berdasarkan karakter morfologi dan fitokimia di Hutan PT. Chevron Pacific Indonesia (PT. CPI) Rumbai. Jurnal Riau Biologia 1(2): 165172.

Zhang, X. C., S. G. Lu, Y. X. Lin, X. P. Qi, S. Moore, F. W. Xing, F. G. Wang, P. H. Hovenkamp, M. G. Gilbert, H. P. Nooteboom, B. S. Parris, C. Haufler, M. Kato \& A. R. Smith. 2013. Polypodiaceae. Pp. 758-850 in Z. Y. Wu, P. H. Raven \& D. Y. Hong, eds., Flora of China, Vol. 2-3 (Pteridophytes). Beijing: Science Press; St. Louis: Missouri Botanical Garden Press 